\title{
O OLHAR RECORTADO: CONSIDERAÇÕES SOBRE O PONTO DE VISTA NA ADAPTAÇÃO CINEMATOGRÁFICA DE EU RECEBERIA AS PIORES NOTÍCIAS DOS SEUS LINDOS LÁBIOS
}

\author{
Marcelo Bulhões* \\ Faculdade de Arquitetura, Artes e Comunicação - UNESP \\ Ricardo Magalhães Bulhões ${ }^{* *}$ \\ Universidade Federal do Mato Grosso do Sul
}

\begin{abstract}
Resumo: Avaliar a adaptação cinematográfica de Eu Receberia as Piores Notícias dos seus Lindos Lábios, filme dirigido por Beto Brant e Renato Ciasca, baseado no romance do mesmo título de Marçal Aquino, é o propósito deste artigo. Tanto no romance quanto no filme, a todo momento, o leitor/telespectador é convidado a lidar com a visão tensa de um narrador personagem que conta sua própria história compondo espécies de flashes das suas traumáticas lembranças. Em um movimento de vaivém, quase sempre entrecortado pelas falas e relatos de personagens secundários, o protagonista encarna a figura de um narrador angustiado, que não consegue se livrar de conflitos que o assombram, sobretudo a lembrança de Lavínia, mulher sedutora e enigmática por quem se apaixonara. Neste nosso texto, o interesse recai sobre o problema do ponto de vista. No filme a natureza ótica do meio cinematográfico inscreve o olhar na estrutura da ação dramática. Assim, a questão do ponto de vista desponta como categoria decisiva reveladora das próprias especificidades da literatura e do cinema.
\end{abstract}

Palavras-chave: Literatura Brasileira Contemporânea. Adaptação. Cinema. Ponto de vista.

No campo das relações entre cinema e literatura, a questão da adaptação parece ocupar uma posição de destaque pelo interesse que suscita. A inumerável quantidade de filmes "baseados" em obras literárias é naturalmente o sinal mais evidente de tal interesse. Tendo percorrido toda a trajetória do cinema, não é de estranhar, pois, que a adaptação tenha

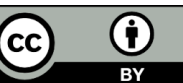

Esta obra está licenciada sob uma Creative Commons - Atribuição 4.0

\footnotetext{
* Livre-docente pela UNESP, doutor em Literatura Brasileira e mestre em Teoria Literária e Literatura Comparada, ambos os títulos pela USP. Possui licenciatura em Letras pela UNESP. Professor do Curso de Comunicação Social da UNESP, onde ministra disciplinas de literatura e língua portuguesa. Compõe o programa de Pós-graduação em Comunicação da mesma instituição. E-mail: bulhoes@,faac.unesp.br.

** Graduou-se em Letras na Universidade Estadual Paulista Júlio de Mesquita Filho; (UNESP Assis) no ano de 1986, onde concluiu o Mestrado (1992) e o Doutorado (2007), ambos na área de Literatura e Vida Social. Atualmente é Professor Adjunto 4 na Universidade Federal do Mato Grosso do Sul (UFMS), Campus de Três Lagoas, atuando na Graduação e Pós-graduação em Letras. E-mail: ricardoufms1@gmail.com
}

Anu. Lit., Florianópolis, v. 20, n. 2, p. 25-41, 2015. ISSNe 2175-7917 
despertado (e continue despertando) a atenção de estudiosos de distintas áreas, como história, teoria literária, semiótica - além, naturalmente, da teoria e da história do cinema -, entre outras, pelas diversas colorações teóricas e analíticas de que se reveste, pelos problemas que fomenta, pelos dividendos reflexivos que produz.

Quer se fale em tradução ou adaptação, vale já assinalar a impossibilidade de equivalência completa dos meios de expressão na "passagem" do literário ao fílmico, diante da qual a exigência ou a expectativa - tácita ou explícita - de fidelidade resulta precária e mesmo ingênuas diante da inevitável mutação de toda tradução intersemiótica ${ }^{1}$. Toda adaptação é sempre um processo de criação, um fenômeno afeito ao engenho da reelaboração, sejam nas obras adaptadas que buscam produzir um efeito de semelhança em relação às obras originais, sejam as que acentuam o próprio traço distintivo, para não dizer discordante, em relação à obra “matriz”. Derivada e compatível com tal perspectiva é uma postura analítica e crítico-valorativa que reconhece o caráter de autonomia da obra resultante do processo adaptativo. No caso da tradução do literário para o cinematográfico, tal atitude deve acolher deliberações, proposituras estilísticas, inflexões formais próprias do meio cinematográfico.

Tais considerações se endereçam ao "caso" da adaptação de Eu Receberia as Piores Notícias dos seus Lindos Lábios, filme dirigido por Beto Brant e Renato Ciasca lançado em 2012, baseado no romance do mesmo título, de Marçal Aquino, publicado em 2005. Tomamos o filme de Brant e Ciasca, cujo roteiro é do próprio Aquino, para tratarmos de uma questão que conduz o problema da adaptação do literário para o audiovisual ao cerne de uma investigação que julgamos crucial: a instância narrativa responsável por dar a conhecer a informação diegética - o que nos estudos do cinema costuma ser designado como ponto de vista - em sua relação com o que os estudos literários designam como focalização, foco narrativo ou mesmo visão (além da própria nomeação ponto de vista). De fato, o problema do ponto de vista é decisivo para um exercício analítico, à guisa de cotejo, que queira flagrar as marcas expressivas das conformações da instância narradora do discurso literário e do discurso fílmico, levando à notação de singularidades dos dois meios. Nossa intenção é avaliar o comportamento da instância narrativa em que a questão do olhar funcionaria como aspecto estruturante da própria construção do discurso narrativo na "passagem" do literário ao cinematográfico.

Algumas balizas teóricas da questão do ponto de vista/focalização são naturalmente necessárias.

\footnotetext{
${ }^{1}$ Designação usada por Jakobson no célebre texto "Aspectos Linguísticos da Tradução" (1968) para se referir à interpretação dos signos verbais por meio de sistemas de signos não-verbais.
} 


\section{Na Mira: focalização e ponto de vista}

Tradicionalmente, os estudos literários representam o campo que mais dividendos rendeu ao problema da focalização - ou ponto de vista - dada a própria precedência cronológica da teoria literária em relação a campos de estudo que se dedicam às narrativas audiovisuais. Não é de estranhar, pois, que os estudos de cinema tenham em alguns momentos recorrido a tal tradição teórica anterior - assim como recorreu à teoria das artes plásticas e do teatro. Mas seus passos não representam simples tributo ou mera transposição com ajustes do repertório conceitual e do instrumental metodológico dos estudos literários. Há diálogo entre teorias e expedientes analíticos que têm servido para assinalar a própria especificidade da expressão cinematográfica. Ao mesmo tempo, os estudos cinematográficos há tempos demonstram maturidade no tratamento da questão do ponto de vista compatível com a importância que o problema possui em uma expressão na qual a visualidade parece fazer parte de sua ontologia.

O ponto de vista ou focalização constitui uma categoria crucial para a teoria da narrativa. Definindo-se como a representação da informação diegética à disposição de um determinado campo de consciência - seja um personagem ou um narrador em "terceira pessoa" -, o ponto de vista não somente diz respeito à quantidade da informação narrativa, mas abrange aspectos qualitativos, pois traduz posições afetivas, éticas e ideológicas da instância responsável pelo narrar. Embora possa ser mais difícil identificar as marcas do sujeito da enunciação narrativa em um filme do que em um romance, ambas são expressões calcadas no narrar, o que supõe a existência da instância responsável por enunciar a informação diegética. No entanto, ponto de vista, focalização ou visão em narrativa literária são designações com claras conotações visualistas, as quais parecem estar mais à vontade no meio cinematográfico - e no campo audiovisual de modo amplo. E se os estudos de cinema têm utilizado ponto de vista, em vez de perspectiva narrativa ou voz narrativa, é que tal variação tipológica comporta um dos distintivos entre a própria expressão cinematográfica e a literária: diferentemente de um gênero literário como o romance, ponto de vista em cinema possui um sentido primordial não metafórico, uma vez que a visualidade ocupa o cerne da manifestação cinematográfica.

Antes de tudo, ponto de vista em cinema refere-se a um fato de natureza ótica: é o posicionamento da câmera, o lugar desse aparato que dispõe um "olho" por meio do qual o mundo é captado e tornado imagem exibida na tela. O "olho" da câmera capta e dá a ver o mundo ao espectador, cuja mirada só pode coincidir com esse "olho mecânico". Assim, o 
trabalho da enunciação narrativa no cinema parte da existência de uma instância que primeiro "olhou" o mundo e o "recortou", tornando-o plano cinematográfico. E esse "olho" da câmera pode se movimentar, escolher ângulos, desfocar-se, recortar espaços - menores (close, plano detalhe) ou maiores (plano geral), etc. Vale salientar, pois, o processo fundamental que torna o ponto de vista ótico um ponto de vista narrativo. Tal processo se faz, de um lado, com o arranjo das distintas posições da câmera, em que se estabelece um "lugar imaginário" do olhar do espectador, o qual se relaciona com o trabalho da montagem. De outro lado, atuam os elementos auditivos, que se relacionam com a imagem. Assim, no cerne da narratividade, as imagens e os sons de um filme tanto podem corresponder a uma instância anônima quanto a um personagem inserido na diegese, o que corresponderia respectivamente, de maneira geral, aos modos heterodiegético e homodiegético do narrador do romance, segundo a conhecida terminologia de Gerárd Genette (1972).

Diferentemente da literatura, a dupla natureza do cinema, narrativa e "mostrativa", é condição que, em alguma medida - muito própria da chamada narrativa cinematográfica clássica - facilita o escamoteamento da entidade responsável pelo narrar, construindo-se um poder persuasivo ou ilusionista, um efeito que faz aparentar como realidade o que é criação ficcional. Sabe-se que tal atitude, a qual produz a impressão de que a história transcorre sem a intervenção da câmera, ocultando-se a mediação, há tempos serve à associação com o padrão narrativo da literatura realista-naturalista do XIX. Em determinados filmes, o camuflar da câmera agregado à sua ubiquidade compõem um padrão que corresponderia ao do narrador heterodiegético e onisciente do romance tradicional. De outro lado, a explicitação do narrador literário encontraria similitudes no relato subjetivo que se ancora numa voz over de um narrador visualmente identificado na tela cinematográfica como personagem. Outros modos de disposição da instância fílmica narradora, desconcertantes, como a concorrência de um "olhar externo" da "câmera narradora" com uma multiplicidade de vozes pertencentes a diversos personagens que também narram, caso célebre em Cidadão Kane (1941), podem ser associados ao combate da onisciência do modelo realista por expedientes do romance moderno, no cume das vanguardas do século XX.

Todavia, deve-se lembrar que, de um modo geral, a narração em "primeira pessoa" no cinema só parece encontrar associação válida em sentido estrito por meio do conteúdo sonoro. Afinal, qualquer personagem que pronuncia um “eu” em um filme é desde já um 
“ele", pois sua imagem se impõe na tela ${ }^{2}$. Não são raros os filmes em que além do "olhar da câmera", um "olhar de fora", que corresponderia ao do narrador heterodiegético do romance ou do conto, atua um narrador em primeira pessoa, portador de uma voz over, que frequentemente desempenha a função de personagem-protagonista. Assim o que é mostrado na tela necessariamente não coincide com o campo de visão desse ser ficcional; o que se exibe na composição da imagem acaba superando o olhar desse personagem incumbido de nos contar algo. Pois, embora se pudesse arriscar o que a teoria da literatura chama de focalização interna, com a presença de um personagem assumindo a perspectiva de quem nos enuncia os acontecimentos, sua imagem também nos é revelada; ou seja, ele é flagrado por uma focalização externa que mostra, inclusive, o que ele não vê.

A propósito, tais questões que envolvem o "interno" e o "externo" são atinentes à verificação do(s) modo(s) de narrar de Eu Receberia as Piores Notícias de seus Lindos Lábios. Do romance ao filme, é preciso conferir.

\section{Um Romance do Desejo e do Olhar}

No romance Eu Receberia as Piores Notícias dos seus Lindos Lábios, a memória do narrador-personagem - Cauby, um fotógrafo - e sua relação com a câmera fotográfica funcionam, em larga medida, como um dos vetores mais importantes da construção narrativa. Em larga medida, o enredo, o tempo e o espaço são enfeixados pela ótica de um narrador que explicita o ato de configurar imagens, mediadas por uma câmera fotográfica, que ora se aproxima, ora se distancia dos objetos focados. Em cerca de dois terços da narrativa, nos capítulos "O Amor é Sexualmente Transmissível", "Postais de Sodoma à Luz do Primeiro Fogo", "Poema Escrito com Bile", o leitor transita de uma situação narrativa a outra, de um assunto a outro, guiado pela interferência do narrador Cauby, que traz os fatos a partir da "edição" das imagens da sua Pentax.

Nesses três capítulos, a todo o momento o leitor é convidado a lidar com a visão tensa de um narrador-personagem, o eu-protagonista segundo Friedman (2002), que conta sua própria história compondo espécies de flashes das suas dolorosas lembranças. Em um movimento de vaivém, quase sempre entrecortado de falas e relatos de personagens secundários, o protagonista encarna a figura de um narrador angustiado, que não consegue se livrar de traumas que o assombram, sobretudo a lembrança de Lavínia, mulher sedutora e

\footnotetext{
${ }^{2}$ E raríssimos são os casos como A Dama do Lago (1947), filme dirigido por Robert Montgomery, cuja narrativa é integralmente conduzida em câmera subjetiva: tudo o que se vê na tela se dá a partir do ponto de vista do narrador-protagonista, o detetive Marlowe. Assim, ele aparece na tela somente quando se mira em um espelho; ao olharem diretamente para ele, os personagens olham para a câmera, ou seja, para nós, espectadores.
} 
enigmática por quem se apaixonara. Como se não conseguisse respirar direito, pausando o que é rememorado, sua atitude é um movimento em círculos em busca do que ficou para trás; quase se paralisando pelo sentimento de perda, pela fragilidade da sua condição, seu precário estado de espírito. A memória individual desse narrador fragilizado é o ponto de partida da narração, desde as primeiras linhas em que seu perfil psicológico e sua precariedade são dirigidos ao leitor em atitude metanarrativa: "Não adianta explicar. Você não vai entender. Às vezes, como num sonho, vejo o dia da minha morte. É uma coisa meio espírita, um flash. E, embora a mulher não apareça, sei que é por causa dela que estão me matando" (AQUINO, 2005, p. 11).

Nessas páginas iniciais do romance, que apontam para a falta de linearidade dos acontecimentos, a narração se dá com o efeito de produção de imagens, selecionadas de um espaço recortado, a pensão de dona Jane, situada numa cidade do garimpo, interior do Pará. Ele especula e observa personagens "avulsas" que passam e se submetem ao seu campo de visão. O narrador Cauby opera, então, como por meio de uma seleção de imagens ofertadas ao leitor. A narração dá-se como associação entre narrar e manipular a câmera fotográfica, enfatizando-se, pois, o processo de mediação: Ajustei e lente na máquina e girei. Dona Jane descruzou os braços, mexeu no cabelo, mostrando os pelos que despontavam nas axilas. Meu nariz capturou a fragrância de lavanda de seu corpo" (AQUINO, 2005, p. 19).

Assim, a plasticidade do ato descritivo é naturalmente resultante desse consórcio entre narrar, olhar e fotografar:

\footnotetext{
A brisa que sopra do rio muda de ritmo e se converte num vento espesso, quente, que agita as samambaias de dona Jane. As folhas roçam o rosto do careca, que as repele. Seu gesto é inútil e ele é obrigado a mudar a cadeira de lugar. Não demora e os pingos enormes começam a bater no calçamento da rua. (AQUINO, 2005, p. 31).
}

Como em um zoom de câmera fotográfica, manipulada pelo protagonista-fotógrafo, mais do que o mero relatar o narrador desvela impressões do que se passa no espaço, no aqui e no agora, encaixando episódios menores, histórias de traições, desencontros. Numa narrativa in medias res (GENETTE, 1979), Cauby é um narrador angustiado, que tenta recompor sua história de amor com Lavínia, mulher do pastor Ernani, a qual conhecera de forma casual na loja de filmes do chinês Chang. Lavínia é, antes de tudo, vítima de uma sucessão de violências, como o estupro, a dependência química do álcool e drogas, a prostituição nas ruas de Vitória, até ter sido resgatada e "salva" por Ernani. O caráter vago das impressões iniciais reveladas por Cauby associa-se à psique fragmentada de um narrador que tenta se recuperar 
de traumas - linchamento, perda do olho direito, sumiço de Lavínia -, sem expectativas de que o ocorrido seja reversível.

No difícil embate com a memória, o narrador-fotógrafo se mostra, embora cheio de dúvidas e incertezas, condutor absoluto dos caminhos da narrativa. É de fato um narrador atuante, que não coleciona opiniões alheias (CARVALHO, 2012). E em lembranças de quando clicou sua Pentax, ele promove o desvendamento da nudez de Lavínia e faz emergir o olhar desejoso do personagem masculino, em que o focalizar da imagem dá-se como ação do desejo:

Fotografei Lavínia em centenas de ocasiões. Todo tipo de ângulo. Como se quisesse documentar cada um de seus poros. Mas, para falar a verdade, em nenhuma outra foto ela aparecia tão bela quanto a sequência que eu fiz naquela tarde [...]. Acho que foi a grande foto de uma mulher que fiz em toda a vida. Uma imagem preciosa. Daquelas que justificam guardar o negativo num cofre de banco. Perdida para sempre. Pena. (AQUINO, 2005, p. 36).

O fragmento é significativo para a percepção da representação erótica a partir da operação atuante do ato de fotografar/mirar, com a escolha do enquadramento, do ângulo, requisito adotado por um narrador que atua como um voyeur autorizado, que ora se aproxima, ora se afasta do corpo de Lavínia. Os acontecimentos são esboçados a partir da figura de um narrador que explica o próprio ato de fotografar, empreendimento que, no âmbito do enredo, mudará sua trajetória para sempre. Paralelamente, nessa altura da narrativa, em que se dá o encontro inicial de Cauby com o olhar sedutor de Lavínia, sua modelo, o narrador introduz com sua fala o olhar da retratada, que exibe seus gostos, o que produz na trama certo ar enigmático:

Ela enamorou-se também pela imagem da escadaria de uma casa de madeira em Nova Orleans, os corrimãos tomados por uma trepadeira viçosa. E ainda por um conjunto de janelas coloridas (Marechal Deodoro, Alagoas). Achei intrigante: Lavínia não gostava mesmo de fotos com gente. (AQUINO, 2005, p. 27).

$\mathrm{Na}$ segunda parte do romance, "Carne Viva", todavia, elege-se outro modo de focalização. Ao tratar do passado desamparado de Lavínia, de seu encontro casual com o pastor Ernani nas ruas degradadas de Vitória, o discurso narrativo é tomado integralmente pelo modo "em terceira pessoa" - heterodiegético, segundo a designação de Genette (1972). Com tal mudança, o discurso literário traz pequenas histórias, paralelas ao núcleo central da trama, entre Lavínia e o pastor Ernani pelas ruas de Vitória; episódios que apontam para um 
cenário degradado, o mundo cão das ruas, das drogas, da prostituição ${ }^{3}$. Ao mesmo tempo, ao desaparecer a focalização em "primeira pessoa" do atormentado Cauby, ameniza-se muito a tensão anterior, deixando o leitor "tomar fôlego". O fundamental aí é perceber que em "Carne Viva" o foco narrativo "externiza-se", com a assunção de um modo de narrar em que a diegese não advém do campo de consciência do protagonista-fotógrafo. Há onisciência de uma focalização "externa" e intrusa, que se adentra nos pensamentos das personagens, expondo ao leitor inseguranças, medos, traumas gerados por ações do passado:

Em geral, Lavínia detestava abordar o passado. Significava reabrir feridas, revisitar um mundo de privações e violências [...]. Uma de suas mentiras prediletas: apresentar-se como ovelha negra de uma família capixaba tradicional, uma família arruinada, que a obrigava a prostituir-se para pagar dívidas. Fantasias que serviam para protegê-la da lembrança dos episódios de uma dureza absurda de seu passado. Um pântano pegajoso que ainda a atormentava. (AQUINO, 2005, p. 97).

No capítulo "Postais de Sodoma à Luz do Primeiro Fogo", a voz individualizada do protagonista - em "primeira pessoa" - retorna, permanecendo até o fim do romance. Ele recupera as imagens do momento em que se vê envolvido pela violência sem limites, pela luta descontrolada pelo poder, o mundo cão da justiça pelas próprias mãos, mundo dos extermínios, dos apedrejamentos.

Importante é salientar que a questão do olhar associada ao desejo amoroso no romance de Aquino se desenvolve com mudança de foco narrativo, com a separação entre um "olhar interno" - do protagonista - e um "externo", postura de um foco intruso e onisciente. O olhar se estende como dimensão da constituição do foco narrativo, ou seja, enquanto em Cauby-narrador-protagonista o discurso que foca está tomado pela precariedade do desejo e do tomento, há, no meio do romance, à guisa de flash back, um modo mais ponderado, produzido pelo efeito de "exterioridade" do modo heterodiegético. Tal equação que envolve “interno" e "externo" nos interessa de perto à avaliação da adaptação cinematográfica.

\section{Filme: o olhar que deseja}

Se há pouco falávamos em "visão tensa", "flashes", "ótica de um narrador" a "configurar imagens" ou "campo de visão" a respeito do romance de Marçal Aquino, é flagrante a conotação visualista de tais designações, uma vez que o olhar é questão

\footnotetext{
${ }^{3}$ Segundo Karl Schollhammer (2009), ao tratar da ficção brasileira contemporânea, sem rodeios nem floreios, autores como Fernando Bonassi, Marcelino Freire e Marçal Aquino abordam temas convulsivos, pungentes. Para Schollhammer, tais autores "abrem caminho para um tipo de realismo cuja realidade não se apoia na verossimilhança da descrição representativa, mas no efeito estético da leitura, que visa a envolver o leitor afetivamente na realidade da narrativa" (SCHOLLHAMMER, 2009, p. 59).
} 
fundamental na obra. Compareceram, pois, com valor operativo ${ }^{4}$, como correlativos do universo verbal ao campo das expressões visuais. Agora, importa flagrar como tal caráter visualista presente no romance vai, na adaptação cinematográfica de Eu Receberia as Piores Notícias dos seus Lindos Lábios, se exercitar no campo de expressão próprio e por excelência da visualidade, o cinema.

$\mathrm{Na}$ adaptação cinematográfica de Beto Brant e Renato Ciasca o olhar terá um papel estruturante na construção da narrativa fílmica pela relação que se estabelece entre o mecanismo ótico da câmera e a subjetividade dos personagens da intriga. Com efeito, explorase o ponto de vista em termos estritamente óticos, o que não cabe ao discurso literário dada sua condição verbal. Fundamentalmente, a associação temática entre o olhar e o desejar encontra na versão cinematográfica uma operação em que o dispositivo ótico da câmera estabelece um colóquio com o olhar desejante dos personagens principais.

Imagem 1 - Primeiro plano de Eu Receberia as Piores Notícias de seus Lindos Lábios: ênfase no evento voyeurístico

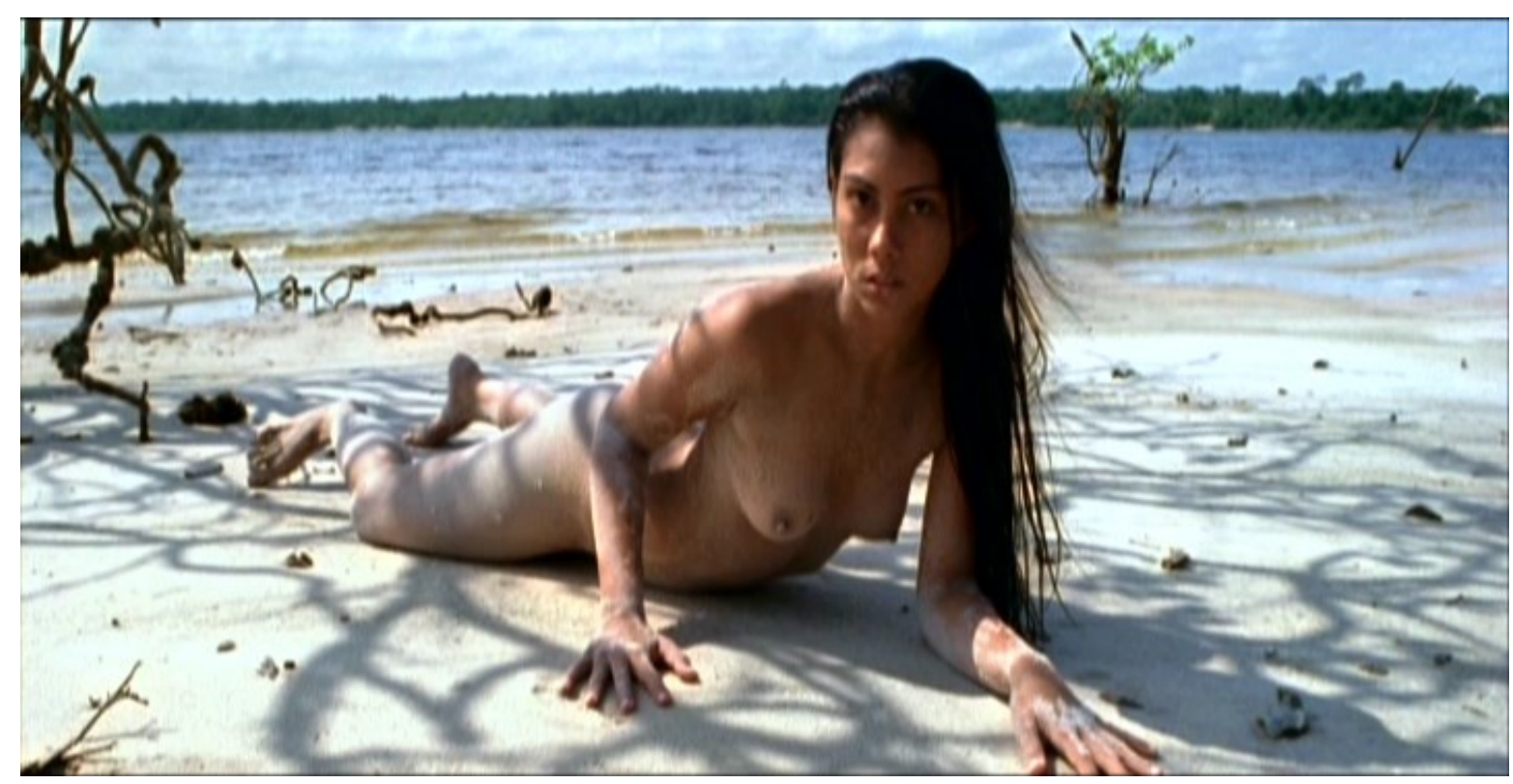

Fonte: Eu Receberia as Piores Notícias de seus Lindos Lábios: Produção: Bianca Villar, Renato Ciasca, Brasil, 2011

O filme estabelece, desde o início, a associação do olhar ao desejar: erotismo no ato de olhar e de ser olhado, voyeurismo e exibicionismo. O primeiro plano do filme traz a imagem de uma bela "nativa" nua, deitada numa ilha de areia ladeada por um rio. Seu corpo está diretamente associado ao ambiente natural - do Norte do Brasil - pela areia que

\footnotetext{
${ }^{4}$ Naturalmente, tal valor operativo está na própria designação ponto de vista e, talvez em grau menor, em focalização.
} 
praticamente o envolve todo, deixando limpo apenas o rosto. Índia, nua, telúrica, seu corpo se curva e toca a areia. A duração do plano é suficientemente longa para enfatizar o evento voyeurístico. Quase sempre ela olha diretamente para a câmera, que pouco se move, e para um espaço off, como se receasse olhares intrusos. Sua feição oferece-se acintosamente ao olhar da câmera e ao mesmo tempo indica que está sendo olhada. Por quem? Por nós, espectadores. Seu olhar dirigido à câmera denuncia a mediação do dispositivo ótico cinematográfico - que franqueia o voyeurismo. Assim, ela se porta como imagem-ídolo, objeto para o desejo do olhar externo. Na performance de um corpo a serviço do exercício ótico, seu olhar "devolve" à câmera cinematográfica o exercício acintoso de olhar: mirando diretamente para a câmera, o olhar dessa "nativa" exibe a ação de se exibir, demonstra a consciência de que compõe uma imagem. Representa, com gestos calculados, o ato de posar e converter-se em imagem.

Imagem 2 - Olhar do protagonista dirigido a um espaço off

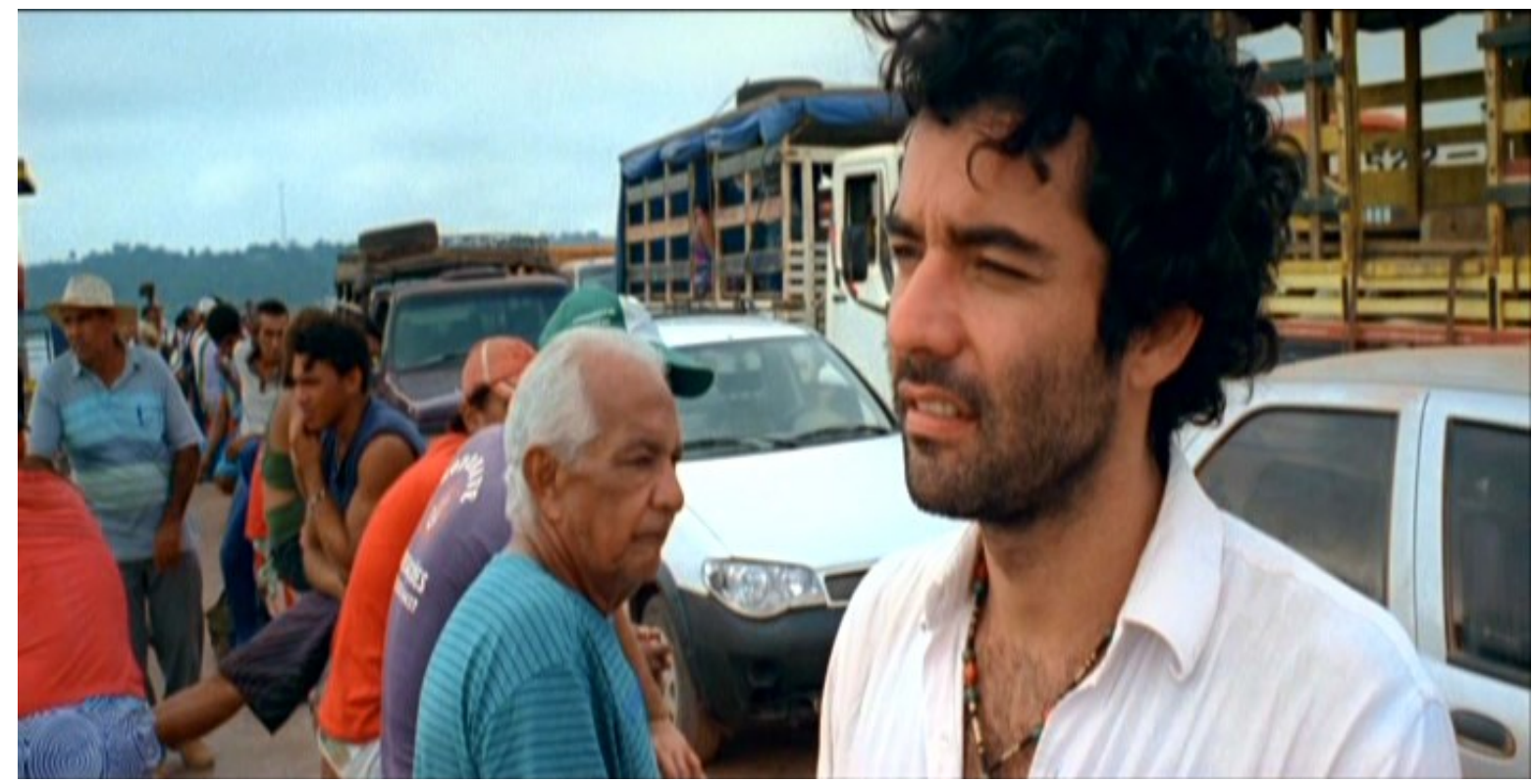

Fonte: Eu Receberia as Piores Notícias de seus Lindos Lábios: Produção: Bianca Villar, Renato Ciasca, Brasil, 2011

O plano seguinte é a de um homem em uma embarcação (Imagem 2), mirando para um espaço off, entre encantado e intrigado. Trata-se do protagonista, Cauby, no momento de sua chegada a uma cidade de garimpo no Pará. Alusivamente, ele parece olhar para a "nativa" nua na $\operatorname{areia}^{5}$, embora não se estabeleça um contra-plano, pois o plano da imagem da "nativa" não mais comparecerá. Mas a justaposição dos dois planos anuncia a questão decisiva do

\footnotetext{
${ }^{5}$ Ressoa o motivo da posse do viajante colonizador europeu do objeto do desejo, a terra e a mulher nativas, que encontra no mito de Iracema uma de suas versões.
}

Anu. Lit., Florianópolis, v. 20, n. 2, p. 25-41, 2015. ISSNe 2175-7917 
filme: desejo e sedução mediados pelo olhar. A adição dos dois planos prenuncia o encontro do fotógrafo Cauby com Lavínia, que será imagem-ídolo do olhar desejante.

Tal abertura se vincula à condição de fotógrafo do protagonista. E a atitude voyeur do protagonista-fotógrafo exercitar-se-á no cerne da singularidade expressiva do meio cinematográfico. O discurso fílmico fará com que a atuação de seu olhar de fotógrafo entre em relativa consonância com o olhar da câmera que responde pelas imagens na tela, em um consórcio entre o olhar voyeur da câmera do protagonista-fotógrafo e o "olho" da câmera que produz as imagens fílmicas. Da transação entre essas instâncias decorrem lances fundamentais da realização fílmica.

Ainda no início do filme, uma cena aparentemente acessória serve para marcar o movimento de consonância entre a perspectiva da câmera cinematográfica e a da câmera fotográfica do protagonista. Numa delegacia, Cauby fotografa um homem preso. A câmera movimenta-se lentamente até um enquadramento quase frontal, em que o rosto do homem detido se levanta para ser emoldurado pelo olhar-câmera de Cauby (Imagem 3). Assim, câmera fotográfica - ponto de vista do olhar do personagem - e câmera cinematográfica ponto de vista "externo" - coincidem pois assumem o mesmo vértice responsável pelas imagens que se exibem na tela. O que costuma ser chamado de plano subjetivo ou uso da câmera subjetiva nesse caso é encontro do olhar-câmera do fotógrafo com o olhar da instância que representaria o olhar "oculto", de fora, que prevalece no filme. Embora, de fato, na maior parte do filme as imagens que vemos não correspondam à "câmera subjetiva" do protagonista em sua ação de fotografar, está dada a senha discursiva do colóquio entre os dois "olhares". Explorando-se o que é específico do discurso cinematográfico - o efeito "mostrativo" no concurso de imagens com função narrativa -, faz-se ambivalente o jogo entre um olhar "de fora" e um olhar "de dentro" da diegese. 

cinematográfica.

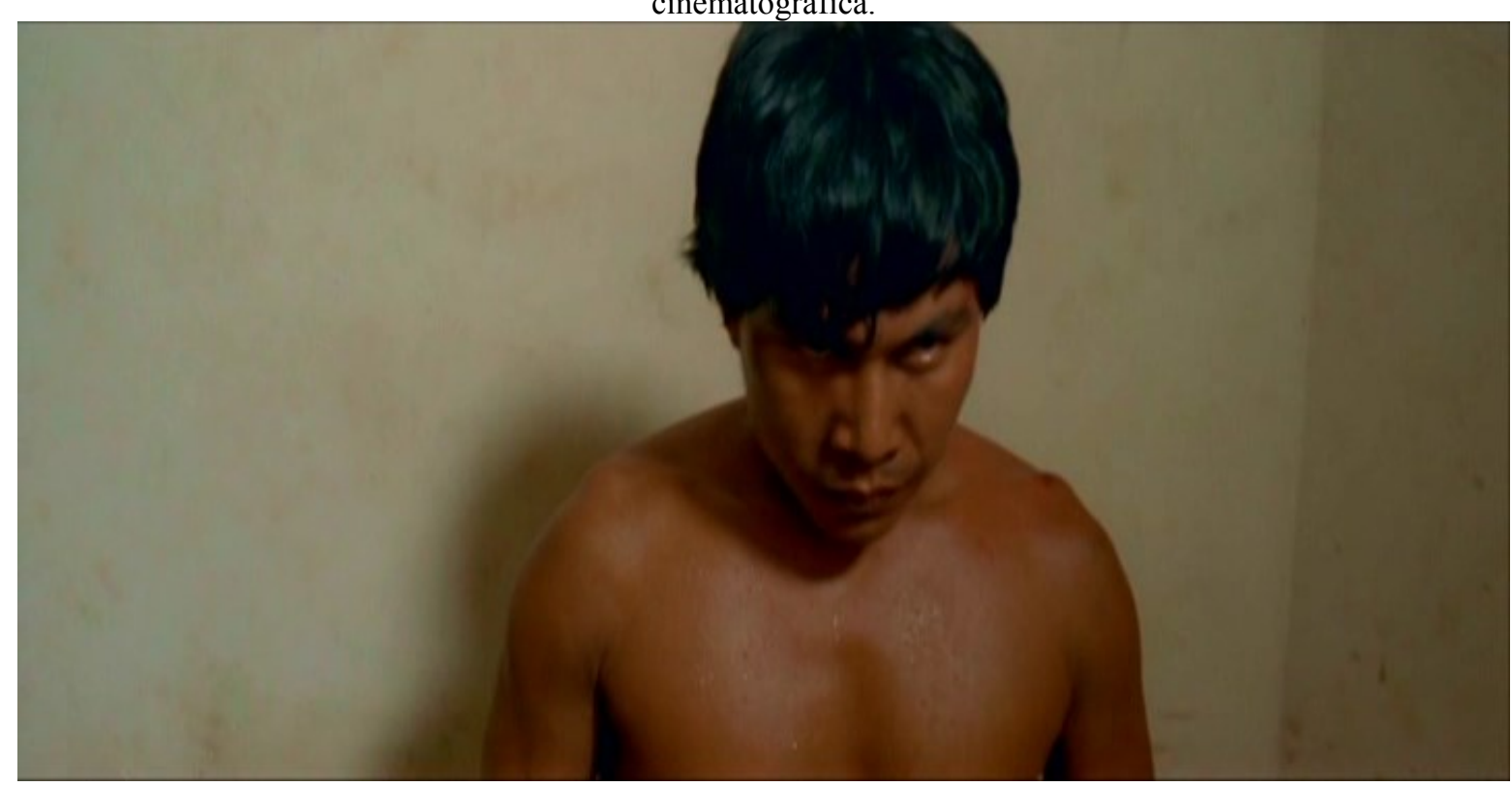

Fonte: Eu Receberia as Piores Notícias de seus Lindos Lábios: Produção: Bianca Villar, Renato Ciasca, Brasil, 2011.

Tal comportamento discursivo é responsável por estabelecer a intersecção entre desejo e olhar; o desejo erótico-amoroso se faz como pulsão escopofílica. Se o olhar é matriz do envolvimento amoroso dos personagens no romance de Aquino, o jogo escopofílico entre eles chega a estruturar a construção das cenas do filme, justamente no consórcio ambíguo entre a câmera do protagonista-fotógrafo, Cauby, e a autoridade narrativa da câmera de cinema, instância mais atuante do ponto de vista.

Em termos mais específicos, no encontro amoroso entre os dois personagens, Cauby fotografa Lavínia, que se exibe sensualmente e é a todo o momento estimulada pelo fotógrafo a esse mostrar-se (Imagem 4). 
Imagem 4 - Na sessão de fotos, o olhar-câmera do fotógrafo é canal para o voyeurismo do espectador.

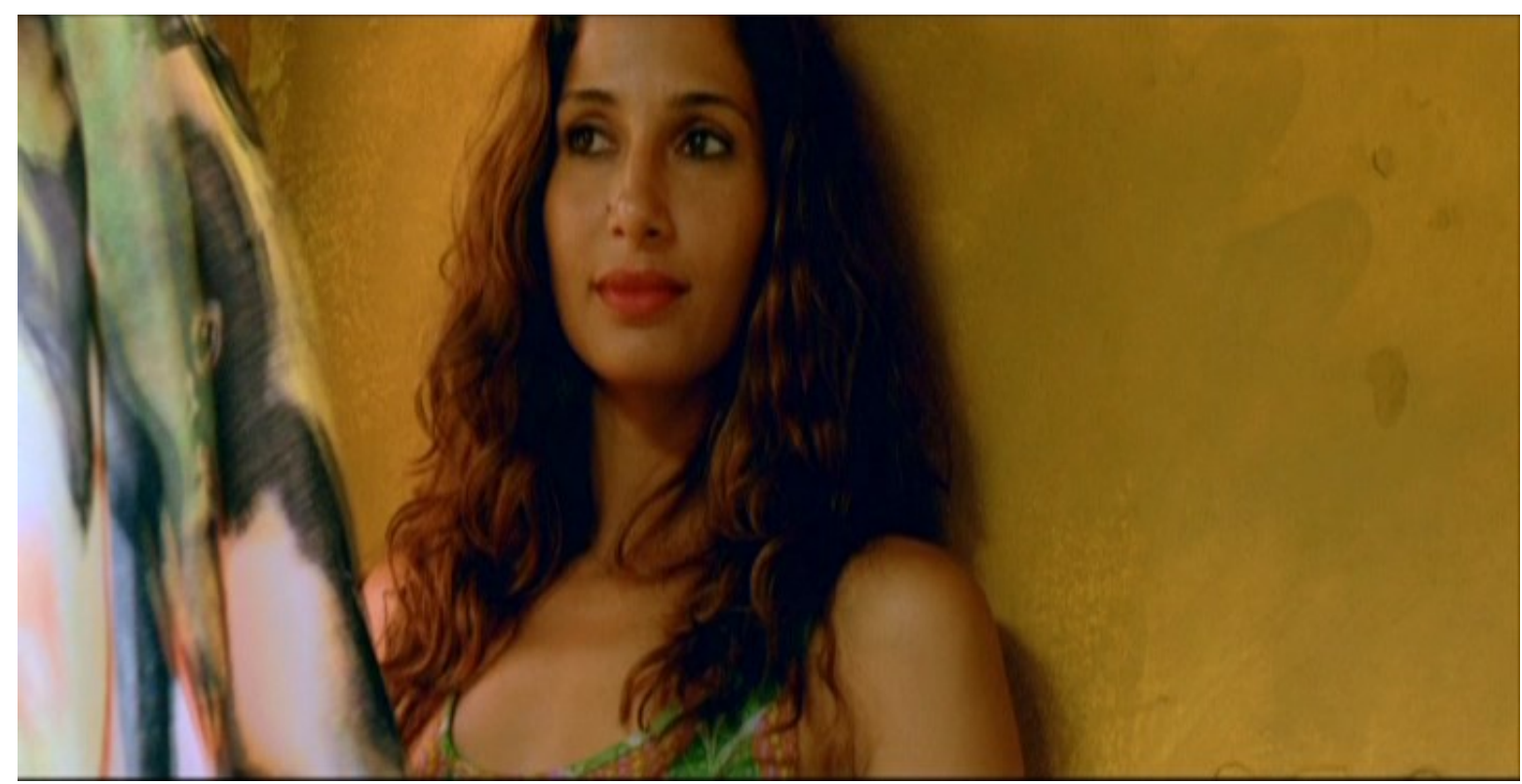

Fonte: Eu Receberia as Piores Notícias de seus Lindos Lábios: Produção: Bianca Villar, Renato Ciasca, Brasil, 2011.

Cauby, à maneira de um diretor cinematográfico, "dirige" Lavínia. E age assim também a serviço do seu próprio voyeurismo de espectador-fotógrafo. Ela é devassada pelo olhar masculino, em que o ver é buscar seduzir e se explicita o ato de ser seduzida por um olhar que também seduz. À intensificação dos clics da câmera do fotógrafo corresponde o avanço da conquista erótico-amorosa. Mais tarde, embora aos poucos, as possibilidades de separação entre os personagens têm a correspondência do recuo do ato de fotografar. Quanto mais ameaçado a história de amor dos dois protagonistas, menos Cauby fotografará Lavínia.

$\mathrm{Na}$ mesma cena e que Cauby fotografa Lavínia, o ponto de vista de um olhar "oculto" diante do objeto do desejo insinua aproximação com o do personagem-narrador da trama, Cauby, que se relaciona diretamente ao do próprio espectador. O olhar do fotógrafo executa o ato de fotografar Lavínia como um corpo-imagem privilegiadamente disposto ao olhar voyeur do espectador, no jogo ambivalente entre a câmera manipulada por Cauby e o ponto de vista do "olhar" da câmera cinematográfica responsável pelas imagens da tela. A condição de fotógrafo do protagonista assinala, pois, o caráter visualista da natureza da linguagem cinematográfica e remete à condição voyeur do espectador. A vinculação entre desejar e olhar diz respeito, a princípio, ao comportamento dos dois personagens principais da trama, Cauby e Lavínia. Mas também concerne, por tabela, à relação entre desejo e espectorialidade cinematográfica. Sub-repticiamente, o filme convida, então, à percepção da relação do espectador com o próprio cinema. 
Essa sessão de fotografia dialoga com o plano de abertura do filme, o da "nativa" nua que olhava para a câmera. Embora Lavínia olhe para Cauby, e seu rosto não se componha frontalmente para a câmera "oculta", há ambivalência ao se sugerir associação do "olho" cinematográfico com o ponto de vista do protagonista. Enquanto Cauby clica com sua câmera, é somente Lavínia quem aparece na tela, o que promove equivalência entre o olhar-câmera do narrador protagonista e a instância do olhar oculto da câmera cinematográfica. É preciso não desperdiçar, então, que na concorrência de instâncias narrativas concernentes à visualidade embora não exclusivas, pois também fazem parte do ponto de vista os elementos sonoros -, o desempenho do ponto de vista assinala o caráter estritamente ótico e desse modo o filme acessa o próprio aspecto temático fundamental de Eu Receberia as Piores Notícias dos seus Lindos Lábios. O ponto de vista fica implicado à dimensão temática da obra; é fator estruturante da experiência de Cauby e Lavínia, a relação entre desejo amoroso e voyeurismo.

Não por acaso, Cauby será ferido no olho - e passa a usar um tapa-olho. A amputação do olho equivale à incisão do desejo e separação dos amantes. O tapa-olho em um fotógrafo apaixonado por sua modelo é metáfora da mutilação do desejo escopofílico. Se desde o início, o olhar do fotógrafo em (relativa) consonância com a da câmera fotográfica concerne à experiência erótica, o olho amputado do protagonista é metáfora da amputação de Eros e ameaça de suspensão da vivência amorosa. Olho amputado, olhar amputado: ausência do campo de visão de Cauby na tela. O protagonista não utilizará, até o fim do filme, sua câmera fotográfica. A partir daí, até a última sequência do filme, não será por meio do olhar do fotógrafo-protagonista que o espectador terá as informações diegéticas na tela.

No final do entrecho narrativo, com a morte do marido, Ernani, e do filho concebido com Cauby, Lavínia é recolhida a uma casa de repouso. Sedada, comporta-se como autômata. Em um reencontro com Cauby, não o reconhece. Não é mais Lavínia, mas Lúcia.

Embora fragilizados, vai se desenhando um reencontro dos amantes. Cena decisiva: diante do rio, Lavínia-Lúcia e Cauby olham para o horizonte. Ele sai momentaneamente e deixa nas mãos dela sua câmera. Logo que retorna, Lavínia-Lúcia posiciona a câmera diante do rosto de Cauby. Assume a posição de fotógrafa - voyeur. Adota, pois, a investida do olhar amoroso. Fotografa Cauby.

O fim do filme traz lance que culmina a atuação do expediente cinematográfico na configuração da subjetividade dos personagens ao enfatizar o colóquio entre ponto de vista do personagem e ponto de vista "externo". E será o momento de reabilitação do olhar desejante do protagonista. Um único plano-sequência acompanha os dois personagens, que vêm de táxi. 
O veículo se vai e ambos dialogam na última troca de olhares. Inicialmente, a perspectiva é o de um ponto de vista de câmera oculta. Lavínia diz para Cauby que quer a foto que ela dele. Os dois se beijam. Vemos Lavínia dirigindo-se ao portão e, logo, ouvimos somente a voz over de Cauby, pois não o vemos na tela. A voz de Cauby chama: "Lavínia". Ela se vira e mira diretamente para a câmera. Estão completamente agregados, então, o olho do fotógrafoamante e o da câmera que produz a imagem de Lavínia (Imagem 5).

Imagem 5 - Último plano do filme: o olhar-câmera do protagonista coincide com o vértice da visão do espectador.

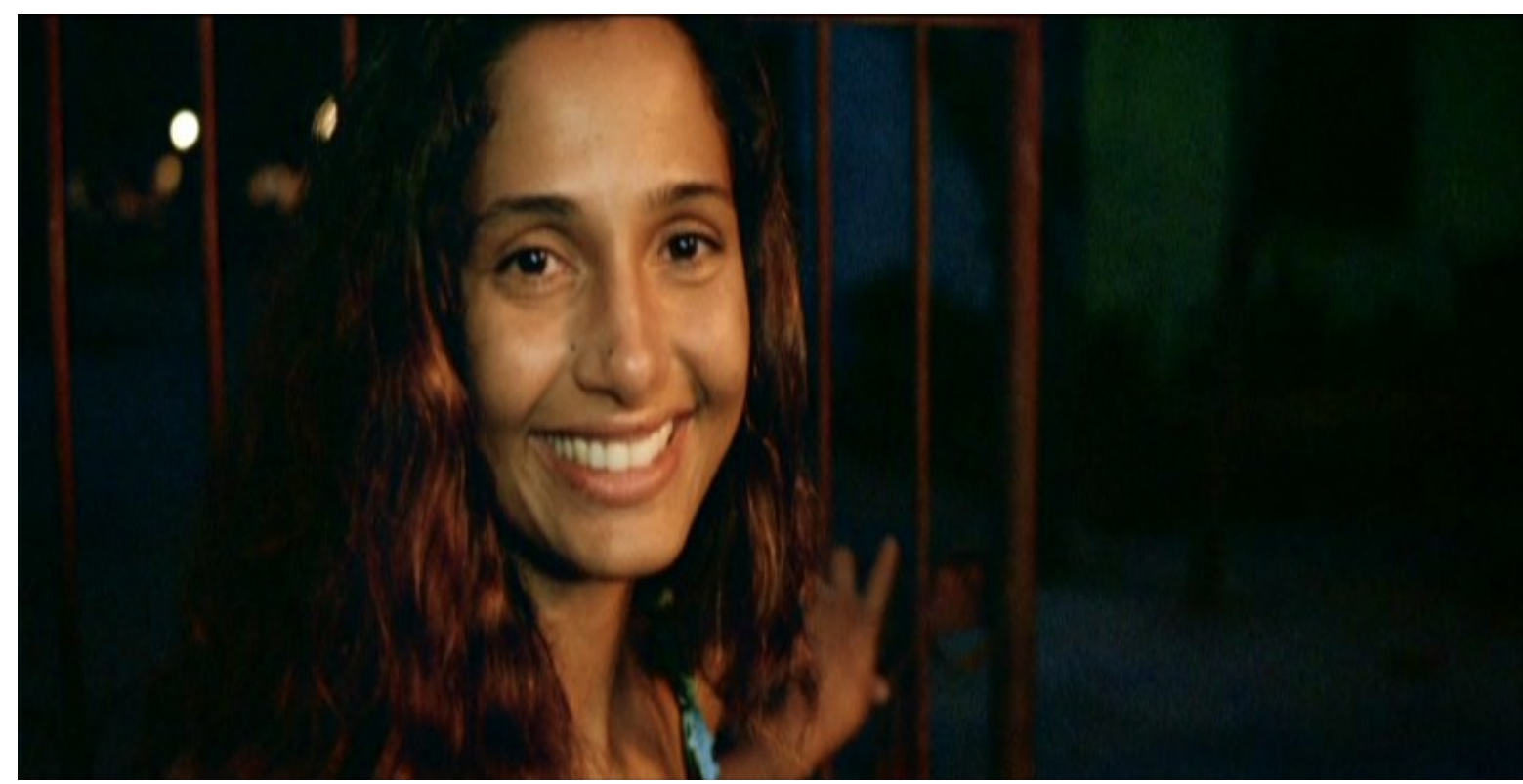

Fonte: Eu Receberia as Piores Notícias de seus Lindos Lábios: Produção: Bianca Villar, Renato Ciasca, Brasil, 2011.

O olhar de Lavínia fica dirigido ao eixo em que estão em total consonância a câmera cinematográfica oculta e a câmera-olho de Cauby, cujas miradas só podem se confundir com o vértice da visão do espectador. Imagem enquadrada, emoldurada, como que produzida a partir da perspectiva do fotógrafo e, por tabela, colhida pelo olhar do espectador. Lavínia sorri, fotografada ou apreendida pelos "dois olhares". A visão do espectador assume, por completo, a perspectiva da instância do olhar amoroso.

\section{Fechando o Olhar}

A adaptação cinematográfica de Eu Receberia as Piores Notícias dos seus Lindos Lábios pode evocar filmes em que a natureza ótica do meio cinematográfico inscreve o olhar na estrutura da ação dramática. Janela Indiscreta (1954), de Alfred Hitchcock, Blow Up (1966), de Michelangelo Antonioni, Dublê de Corpo (1984), de Brian de Palma, Não Amarás 
(1988), de Krzysztof Kieslowski, A Testemunha Ocular (1992), de Howard Franklin, Closer (2004), de Mike Nichols, entre outros, seriam exemplos com os quais o filme de Beto Brant e Renato Ciasca manteria um diálogo intertextual (sem que isso implique situar o filme Brant e Ciasca no mesmo patamar estético). Metanarrativos ou metacinematográficos, tais filmes regem a categoria ponto de vista vinculada ao exercício do olhar como instância fundamental da vivência dos personagens na intriga.

O “caso" de Eu Receberia as Piores Notícias de seus Lindos Lábios nos serviu para flagrar lances expressivos do diálogo entre literatura e cinema com um breve exercício analítico no qual a questão do ponto de vista se mostra categoria decisiva das próprias especificidades dos dois meios de expressão. A questão da visualidade vinculada ao desejo amoroso, à vivência erótico-amorosa dos personagens, aspecto temático central de $E u$ Receberia as Piores Notícias de seus Lindos Lábios, está coligada, tanto no romance quanto no filme, à atuação da instância narradora que nos dá a conhecer a diegese. $\mathrm{Na}$ adaptação cinematográfica a relação entre desejo amoroso e visualidade pôs-se no centro do constructo do discurso fílmico, com a exploração do ponto de vista em termos estritamente óticos, o que não caberia ao discurso literário dada a sua própria condição verbal.

No cenário contemporâneo, de intensas interações e contaminações entre meios e suportes de irrefreáveis simbioses e sincretismos de formatos e gêneros narrativos, o que se avaliou aqui certamente pode valer para o vislumbre da complexidade advinda do direito do criador audiovisual à interpretação e recriação sem amarras do repertório narrativo-ficcional literário, em que a obra resultante do labor da adaptação é usufruída como uma nova experiência estética. Se toda adaptação implica inevitável mutação no âmbito dos meios de expressão, no caso da adaptação fílmica dirigida por Brant e Ciasca de Eu Receberia as Piores Notícias dos seus Lindos Lábios, fundamental foi perceber que o ponto de vista afigura-se como categoria decisiva à questão da adaptação.

\section{Referências}

AQUINO, Marçal. Eu Receberia as Piores Notícias dos seus Lindos Lábios. São Paulo: Companhia das Letras, 2005.

CARVALHO, Alfredo Leme Coelho de. Foco narrativo e fluxo de consciência. São Paulo: Editora UNESP, 2012.

FRIEDMAN, Norman. O ponto de vista na ficção: o desenvolvimento de um conceito crítico. Revista USP, São Paulo, v. 53, p. 166-182, 2002.

GENETTE, Gérard. Discurso da Narrativa. Lisboa: Vega, 1979. 
Figures III. Paris: Seuil, 1972.

JAKOBSON, Roman. Aspectos Linguísticos da tradução. In: Linguística e Comunicação. Tradução de Izidoro Blikstein e José Paulo. 24. ed. São Paulo: Cultrix, 1968. p. 63-72.

SCHOLLHAMMER, Karl Erik. Ficção brasileira contemporânea. Rio de Janeiro: Civilização Brasileira, 2009.

Crédito das Imagens: Eu Receberia as Piores Notícias de seus Lindos Lábios: Direção: Produção: Bianca Villar, Renato Ciasca; Direção: Beto Brant, Renato Ciasca; Brasil, 2011.

[Recebido em abril de 2015 e aceito para publicação em junho de 2015]

\section{The Clipped View: Ponderings on the Point-of-view in the Cinematographic Adaptation of Eu Receberia as Piores Notícias de seus Lindos Lábios}

Abstract: This paper was carried out to assess the cinematographic adaptation of $E u$ receberia as Piores Notícias dos seus Lindos Lábios, directed by Beto Brant and Renato Ciasca, based on the novel with the same title by Marçal Aquino. Both in the novel and in the film, every moment, the reader/viewer is invited to deal with the narrator-character's tense vision telling his own story connecting flashes of his own traumatic recollections. In a swinging movement, most of the time intersected by lines and accounts of supporting characters, the protagonist embodies the character of an afflicted narrator, who does not manage to get rid of haunting conflicts, mainly of Lavínia, a seductive and enigmatic woman with whom he had fallen in love. In our paper, the main interest is focused on the point-ofview. In the film the optical nature of the cinematographic medium takes a look into the structure of the dramatic action. Thus, the issue of the point-of-view stands out as a decisive category which reveals the very specificities of both literature and the cinema.

Keywords: Contemporary Brazilian Literature. Adaptation. Cinema. Point-of-view.

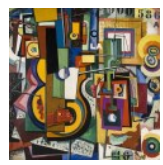

